\title{
Biochar and vermicompost improve growth and physiological traits of eggplant (Solanum melongena L.) under deficit irrigation
}

\author{
Mohsen Ebrahimi ${ }^{1}$, Mohammad Kazem Souri ${ }^{*}$, Amir Mousavi ${ }^{3}$ and Navazolah Sahebani ${ }^{4}$
}

\begin{abstract}
Background: Drought is one of the most important environmental stresses that can adversely influence soil properties, plant growth, and productivity of agricultural crops including eggplant as an important vegetable crop. In recent years, the use of agricultural wastes has been reported as a beneficial and sustainable measure in soil water retention and fertility enhancement. In this study, the effect of date palm and pistachio biochar, vermicompost and a combination of biochar and vermicompost was evaluated on eggplant growth, yield and water use efficiency under deficit irrigation.
\end{abstract}

Materials and methods: The experiment was done in a split-split plot based on randomized complete block design with three replications and under open field conditions. The main plot was deficit irrigation in three levels of 100, 75 and $50 \%$ of plant water requirement (PWR), and the sub-plots were vermicompost in two levels of $0,1500 \mathrm{~g} \mathrm{~m}^{-2}$, and biochar in three levels of $0,500 \mathrm{~g} \mathrm{~m}^{-2}$ of the pistachio biochar and $500 \mathrm{~g} \mathrm{~m}^{-2}$ of the date palm biochar.

Results: The results showed that soil amendment with vermicompost and pistachio biochar and 100\% PWR showed the best plant growth and performance. The early crop yield was highest under pistachio biochar and 50\% PWR, while the total plant yield was highest under combined application of vermicompost and pistachio biochar at 100\% PWR. The plant water use efficiency was maximum under mixed application of vermicompost and pistachio biochar at 50\% PWR. Application of both pistachio biochar and vermicompost at 100\% PWR resulted in the highest leaf concentrations of nitrogen, phosphorus, potassium, iron and manganese. The highest levels of physiologically important stress metabolites, including malondialdehyde, guaiacol peroxidase, superoxide dismutase and catalase enzymes were found in treatments without amendments or only with vermicompost and 50\% PWR.

Conclusion: The results indicate that under normal and particularly water deficit conditions, vermicompost and biochar increased eggplant vegetative growth, yield and water use efficiency.

Keywords: Antioxidant enzymes, Biochar, Vermicompost, Vegetable, Water use efficiency, Yield

\section{Background}

Eggplant (Solanum melongena) is an herbaceous vegetable from the Solanaceae family, which is mainly grown in tropical and subtropical regions for its edible fruits. Eggplant is the fifth most economically important

\footnotetext{
*Correspondence: mk.souri@modares.ac.ir

${ }^{2}$ Department of Horticulture, Faculty of Agriculture, Tarbiat Modares

University, Tehran, Iran

Full list of author information is available at the end of the article
}

Solanaceous crop after potato, tomato, pepper, and tobacco [36].

Drought represents one of the most important environmental stresses that can negatively influence soil physiochemical and biological properties, as well as the growth and productivity of crops including eggplant [12]. In many regions particularly in arid and semi-arid conditions, drought stress is generally associated with enhanced soil salinity and degradation mainly due to high 
evaporation [32]. On the other hand, addition of organic matter and soil amendments can benefit many soil characteristics including soil water retention and crop productivity. Animal manures are a significant source of the organic compounds in cropping systems that have been used since ancient times, however, these amendments have high electrical conductivity, and their long-term application can increase soil salinity [5, 24].

In recent years, the use of agricultural wastes has been reported as a beneficial and sustainable measure, particularly when their bio-processed products such as vermicompost and biochar are applied $[11,40]$. It has been reported that soil amendment with biochar or vermicompost improves soil physicochemical properties including cation exchange capacity, $\mathrm{pH}$, nutrient and water retention, as well as it has promotion effect on soil microbial communities [14, 17, 24, 30, 40]. Furthermore, positive synergistic effects of combining biochar with different compost types have been reported on soil organic content, nutrients levels and water storage capacity $[5,11]$. Replacing peat-based substrate partially by dairy manure vermicompost and biochar (produced by pyrolysis of Pinus monticola wood) improved plant growth and flowering of Petunia hybrida and Pelargonium peltatum [5].

There is increasing interest in application of organic wastes in cropping systems to reduce the adverse effects of drought or salinity stresses [26]. In many parts of the Middle East including Iran, pruned leaves of the date palm and branches of pistachio trees constitute a significant source of organic matter that needs to be processed and handled better and efficiently rather than just burning or piling to rot (with no agricultural usage) that generally contribute in environmental and air pollution. Therefore, this study aimed to evaluate the potential of date palm and pistachio biochar, vermicompost, and their combination on eggplant growth, yield and water use efficiency under deficit irrigation.

\section{Materials and methods}

\section{Experimental site}

The study was carried out from April to September 2018 and in a field located in Shiraz, Iran, with a loamy soil (Calcisol) with a latitude of $29.590^{\circ} \mathrm{N}$ and a longitude of $52.582^{\circ} \mathrm{E}$ at an altitude of $1500 \mathrm{~m}$ above the sea level. The area is characterized by an average annual rainfall of $305.6 \mathrm{~mm}$ and an average annual temperature of $16.8^{\circ} \mathrm{C}$.

\section{Organic materials}

Organic materials used in this study were vermicompost (VC), date palm biochar (DPB) and pistachio biochar (PB). The vermicompost was made from vegetable waste, wheat straw and husk, weeds and cow manure. Healthy and adult individuals of earthworm (Eisenia fetida) were allowed to feed on these organic materials for 90 days and to produce vermicompost. In this study, two types of biochar were produced by slow pyrolysis of the branches and leaves of date palm or pistachio trees at $560{ }^{\circ} \mathrm{C}$ in a transportable ring kiln, at atmospheric pressure with a residence time of $4 \mathrm{~h}$. The physiochemical characteristics of vermicompost, date palm biochar and pistachio biochar are presented in Table 1.

\section{Experimental design and treatments}

The experimental design was a split-split plot based on randomized complete block with three replications. The main plot was deficit irrigation in three levels $[50,75$ and $100 \%$ of plant water requirement (PWR)] and the subplot was vermicompost in two levels $\left(0,1500 \mathrm{~g} \mathrm{~m}^{-2}\right)$ and the sub-sub plot was biochar in three levels $\left(0,500 \mathrm{~g} \mathrm{~m}^{-2}\right.$ of date biochar and $500 \mathrm{~g} \mathrm{~m}^{-2}$ of pistachio biochar). The organic materials were applied at different rates according to treatments and incorporated into the top $40 \mathrm{~cm}$ of soil. Seeds of eggplant cultivar Chantal (Solanum melongena cv Chantal) were germinated in peat moss and 40-day-old seedlings (at four-leaf stage) were transplanted in open field at $50 \mathrm{~cm}$ spacing between plants and $1.5 \mathrm{~m}$ between rows on May 24, 2018. The plants were irrigated using tapes and drip system while weeding and other cultural practices were done regularly during the experiment.

A dripper $\left(4 \mathrm{~L} \mathrm{~h}^{-1}\right)$ was placed next to each plant to measure water consumption. The water requirement of the eggplant was determined according to the FAO Penman Monteith method [3]. The basic plant reference evapotranspiration $(E T o)$ was computed from meteorological data, e.g., minimum and maximum temperature, minimum and maximum relative humidity $(\mathrm{RH})$, dew point temperature (DPT), wind speed at the height of $2 \mathrm{~m}$, and daily sunshine hours and using CROPWAT program. The eggplant water requirement was determined after introducing a proper crop coefficient $(\mathrm{Kc})$ for plants. The comparison of those graphs showed no moisture source other than irrigation during the study period. After determining ETo and crop evapotranspiration (ETc) $(\mathrm{ETo} \times \mathrm{Kc})$, other parameters, e.g., the net and gross irrigation depth (d), the irrigation water need (IN) over the entire growing season, the number of irrigation applications over the whole growing season and the irrigation interval and eventually, the net and gross irrigation water requirements and the gross volume of irrigation water $\left(\mathrm{l} \mathrm{d}^{-1}\right)$ were computed [35].

\section{Soil analysis}

A 500-g soil sample was taken from each plot (3 replications) at the beginning of the experiment (Table 2) as well as at the end of the growing season (Table 5) for soil 
chemical analysis. The soil in the region with an amount of $8-12 \%$ lime was classified as calcisol. The soil $\mathrm{pH}$ was measured potentiometrically in a $1: 5$ soil: $\mathrm{KCl}(1 \mathrm{M})$ extract. Soil mineral nitrogen (nitrate + ammonium) was also measured in a $1 \mathrm{M} \mathrm{KCl}$ extract using a continuous flow analyzer (Skalar San). Soil available potassium was extracted using $0.01 \mathrm{M} \mathrm{CaCl}_{2}$ solution. For determination of the ammonium lactate-extractable $\mathrm{P}, \mathrm{Ca}, \mathrm{Mg}$ and $\mathrm{K}$ in the soil (P-AL, $\mathrm{Ca}-\mathrm{AL}, \mathrm{Mg}-\mathrm{AL}$ and $\mathrm{K}-\mathrm{AL})$, the dried soil samples were ground in a mortar and passed through a $2-\mathrm{mm}$ sieve. Soil samples were mixed with ammonium lactate (extraction ratio 1:20) in dark bottles and shaken for $4 \mathrm{~h}$. The suspension was then filtered and stored at $4{ }^{\circ} \mathrm{C}$ until analysis. $\mathrm{P}-\mathrm{AL}, \mathrm{Ca}-\mathrm{AL}, \mathrm{Mg}-\mathrm{AL}, \mathrm{K}-\mathrm{AL}$ and available $\mathrm{K}$ were analyzed using inductively coupled plasma optical emission spectrometry (ICP-OES, Varian Vista-Pro) with an axial torch. The soil organic carbon $(\mathrm{SOC})$ was determined by dry combustion at $1050^{\circ} \mathrm{C}$ using a Skalar Primacs SLC TOC (Total Organic Carbon) analyzer. The soil total nitrogen $(\mathrm{N})$ was also measured using the Kjeldahl digestion method (BUCHI, Digest automat K-439 and Distillation Kjeldahl K-360).

\section{Plant analysis}

Four months after planting, five plants were sampled randomly from each replicate (plot) to determine the growth parameters and physiological traits of the eggplant. The whole plant was carefully uprooted and cut to shoots and roots. Growth parameters, e.g., shoot fresh and dry weight, root fresh and dry weight, and shoot length were determined. To measure the dry weight, the samples were oven-dried at $70{ }^{\circ} \mathrm{C}$ until a constant weight was achieved.

\section{Determination of chlorophyll $a$ and $b$}

To measure the concentration of chlorophyll a and b, $300 \mathrm{mg}$ of plant fresh leaves was ground in liquid nitrogen with $10 \mathrm{~mL} 96 \% \mathrm{v} / \mathrm{v}$ ethanol. The samples were kept in dark for 2 days at $4{ }^{\circ} \mathrm{C}$. The extracts were then filtered and analyzed by spectrophotometry using a Hitachi U-2000 spectrophotometer (Hitachi Group, Milano, Italy). The absorbance readings were performed at $665 \mathrm{~nm}$ and $649 \mathrm{~nm}$ for chlorophyll a and chlorophyll b, respectively. The amount of chlorophyll a and b was calculated as previously described by Najarian and Souri [26].

\section{Determination of total phenol, antioxidant capacity}

Methanolic extraction of eggplant leaves was performed to determine the total phenol content and the antioxidant capacity. Total phenol content was determined as previously described by Tzortzakis [37]. The antioxidant capacity was measured using the ferric reducing antioxidant power (FRAP) and the 2,2-diphenyl-1-picrylhydrazyl (DPPH) [9].

\section{Determination of leaf ion leakage}

To measure the ion leakage, leaves were rinsed with deionized water and cut into 2-cm-long segments and transferred to glass test tubes containing $10 \mathrm{~mL}$ of deionized water. Tubes with water and leaf segments were placed on a shaker at $20{ }^{\circ} \mathrm{C}$ for $24 \mathrm{~h}$. Then, the electrical conductivity of the samples $\left(\mathrm{EC}_{1}\right)$ was measured (GMH 3430 Conductivity Meter, Greisinger Electronic, Germany). Tubes were incubated at $120^{\circ} \mathrm{C}$ for $2 \mathrm{~h}$. After cooling down the samples at $20{ }^{\circ} \mathrm{C}$ for $20 \mathrm{~min}$, the electrical conductivity $\left(\mathrm{EC}_{2}\right)$ was again measured. Finally, the total electrolyte leakage (EL) was calculated using the following formula: $\mathrm{EL}=\mathrm{EC}_{2} / \mathrm{EC}_{1} \times 100$.

\section{Determination of malondialdehyde and antioxidant enzymes activity}

To determine the concentration of malondialdehyde, $0.5 \mathrm{~g}$ of fresh leaves was homogenized in a $20 \%$ solution of Tris- $\mathrm{HCl}$ buffer $(\mathrm{pH} 7.5)$ containing $0.5 \%$ thiobarbituric acid and incubated at $95{ }^{\circ} \mathrm{C}$ for $25 \mathrm{~min}$. The mixture

Table 1 Characteristics of organic materials used in the experiment

\begin{tabular}{llcrr}
\hline Chemical characteristics & Unit & Vermicompost & Date palm biochar & Pistachio biochar \\
\hline $\mathrm{pH}-\mathrm{KCl}$ & - & $7.5 \pm 0.0$ & $9.0 \pm 0.2$ & $7.7 \pm 0.1$ \\
$\mathrm{EC}$ & $\mathrm{dS} / \mathrm{m}$ & $2.0 \pm 0.3$ & $7.5 \pm 0.8$ & $9.7 \pm 0.8$ \\
Total nitrogen & $\%$ & $2.0 \pm 0.1$ & $0.7 \pm 0.1$ & $0.6 \pm 0.3$ \\
$\mathrm{SOC}$ & $\%$ & $29.0 \pm 1.1$ & $72.0 \pm 4.1$ & $73.2 \pm 2.5$ \\
Phosphorus & $\mathrm{g} / \mathrm{kg}$ & $1.8 \pm 0.2$ & $1.5 \pm 0.3$ & $1.3 \pm 0.1$ \\
Potassium & $\mathrm{g} / \mathrm{kg}$ & $30.1 \pm 2.5$ & $8.3 \pm 0.4$ & $6.4 \pm 0.5$ \\
Calcium & $\mathrm{g} / \mathrm{kg}$ & $47.8 \pm 3.7$ & $5.9 \pm 0.2$ & $6.1 \pm 0.7$ \\
Magnesium & $\mathrm{g} / \mathrm{kg}$ & $10.8 \pm 1.0$ & $3.3 \pm 0.2$ & $3.8 \pm 0.3$ \\
C:N & - & $14.5 \pm 1.6$ & $102.8 \pm 6.2$ & $122.0 \pm 8.5$
\end{tabular}

EC electrical conductivity, SOC soil organic carbon, $C / N$ carbon-to-nitrogen ratio 
Table 2 Physicochemical characteristics of experimental soil

\begin{tabular}{ll}
\hline Field soil chemical characteristics & Amounts \\
\hline Clay-silt-sand \% & $20-30-50$ \\
Lime \% & $8-12$ \\
$\mathrm{pH}-\mathrm{KCl}$ & 7.6 \\
$\mathrm{EC} \mathrm{dS} / \mathrm{m}$ & 5.4 \\
Organic matter (\%) & 2.2 \\
Total nitrogen (\%) & 1.1 \\
Available potassium (mg/kg) & 310 \\
P-AL (mg/kg) & 30 \\
Ca-AL (mg/kg) & 2300 \\
Mg-AL (mg/kg) & 600 \\
K-AL (mg/kg) & 3000 \\
\hline
\end{tabular}

The mineral concentrations were analyzed using inductively coupled plasma (ICP)

$E C$ electrical conductivity, $P-A L$ ammonium lactate-extractable phosphorus, $\mathrm{Ca}-$ $A L$ ammonium lactate-extractable calcium, $M g$ ammonium lactate-extractable magnesium, $K$ ammonium lactate-extractable potassium

was cooled down and eventually, the concentration of malondialdehyde was measured spectrophotometrically at $532 \mathrm{~nm}$ [38].

For other antioxidant enzyme assays, $0.5 \mathrm{~g}$ of fresh leaves was homogenized in $500 \mu \mathrm{L}$ of $0.15 \mathrm{M}$ Tris- $\mathrm{HCl}$ buffer ( $\mathrm{pH} 7.5)$, containing $50 \mathrm{mg}$ polyvinylpyrrolidone (PVP). The homogenate was centrifuged twice at $14,000 \mathrm{~g}$ for $10 \mathrm{~min}$ at $4{ }^{\circ} \mathrm{C}$. The supernatant was used for enzyme activity assays. The total superoxide dismutase (SOD) activity was determined by measuring the inhibition of photochemical reduction of nitro blue tetrazolium (NBT) spectrophotometrically at $560 \mathrm{~nm}$ [13]. The reaction mixture contained $50 \mathrm{mM}$ K-phosphate buffer ( $\mathrm{pH} 7.8$ ), $13 \mathrm{mM}$ methionine, $75 \mu \mathrm{M}$ NBT, $0.1 \mu \mathrm{M}$ EDTA, $4 \mu \mathrm{M}$ riboflavin and the enzyme extract. After adding riboflavin, the tubes were placed under two $15 \mathrm{~W}$ fluorescent lamps for $15 \mathrm{~min}$.

The guaiacol peroxidase (POD) activity was determined by its ability to convert guaiacol to tetraguaiacol. The reaction mixture contained $100 \mathrm{mM}$ K-phosphate buffer (pH 7), $20.1 \mathrm{mM}$ guaiacol, $10 \mathrm{mM} \mathrm{H}_{2} \mathrm{O}_{2}$ and the enzyme extract. The increase in absorbance was recorded by the addition of $\mathrm{H}_{2} \mathrm{O}_{2}$ at $436 \mathrm{~nm}$ for $5 \mathrm{~min}$ [28]. Similarly, the catalase (CAT) activity was determined by monitoring the disappearance of $\mathrm{H}_{2} \mathrm{O}_{2}$ at $240 \mathrm{~nm}$ in a reaction mixture containing $50 \mathrm{mM} \mathrm{K}$-phosphate buffer ( $\mathrm{pH} 7$ ), $33 \mathrm{mM} \mathrm{H}_{2} \mathrm{O}_{2}$ and the enzyme extract [1].

\section{Determination of plant nutrients}

Plant tissues were oven-dried at $65{ }^{\circ} \mathrm{C}$ for 3 days, ashed at $500{ }^{\circ} \mathrm{C}$ for $5 \mathrm{~h}$ and acid $(2 \mathrm{~N} \mathrm{HCl})$ digested. Total nitrogen $(\mathrm{N})$ content was determined with Kjeldahl (BUCHI,
Digest automat K-439 and Distillation Kjeldahl K-360) digestion method. Phosphorus $(\mathrm{P})$ content was determined spectrophotometrically (Multiskan GO, Thermo Fisher Scientific, Waltham, MA, USA). The concentration of $\mathrm{Fe}$, and $\mathrm{Mn}$ was measured by atomic absorption spectrophotometer (PG Instruments AA500FG, Leicestershire, UK) and potassium concentration was determined using flame photometry [29].

\section{Yield components and water use efficiency}

The number of fruits per plant, average fruit weight, early yield (the first harvest), total yield and water use efficiency were measured. The water use efficiency was calculated by dividing the yield $(\mathrm{kg})$ by the water volume used in the growing season $\left(\mathrm{m}^{3}\right)$.

\section{Statistical analysis}

The data of the plant and soil analysis were subjected to factorial ANOVA to assess the effect of different amendments and drought stress on eggplant growth. Data were transformed when the assumptions of normality and homogeneity of variances were not fulfilled. The nontransformed data were used to draw the graphs. The differences among the treatments were analyzed with Duncan multiple range test and differences were considered significant when $P<0.05$. These analyses were performed with SPSS Statistics v22.0 (IBM Corp., Armonk, NY, USA).

\section{Results}

\section{Plant vegetative growth}

The deficit irrigation, vermicompost, biochar and their interactions had significant effects on the shoot and root fresh weight $(P<0.05)$. Maximum shoot and root fresh weight were observed in the plots treated with $100 \%$ PWR and a mixture of PB and VC followed by the treatment of $100 \%$ PWR and combined application of DPB and VC, and also the treatment of 100\% PWR and DPB alone (Fig. 1, Table 3). In addition, at all levels of the deficit irrigation, application of $\mathrm{PB}$ or DPB or VC alone or in combination with each other caused a significant increase in the shoot and root fresh weight compared with plots with no amendment. At 50\% PWR, the combined application of $\mathrm{VC}$ and $\mathrm{PB}$ resulted in only $28 \%$ less shoot fresh weight compared to that irrigated with $100 \%$ PWR and the application of these amendments. In other words, a mixed application of $\mathrm{VC}$ and $\mathrm{PB}$ was able to compensate for up to $50 \%$ of water stress damage. Also, root fresh weight in plots with 50\% PWR and amended with both organic materials was more than the treatment of $100 \%$ PWR without VC and PB (226 vs $155 \mathrm{~g}$ ) and nearly 2.4 times more than the treatment of $50 \%$ PWR with no application of $\mathrm{VC}$ and $\mathrm{PB}$. 
The effect of deficit irrigation, biochar amendments and vermicompost and their interactions on the shoot and root dry weight followed the same pattern $(P<0.05)$. Soil amendment with a mixture of PB and VC at $100 \%$ PWR resulted in the highest shoot and root dry weight. The shoot dry weight of eggplants in plots with $\mathrm{PB}$ and VC and 50\% PWR was only $28 \%$ less than that in plots with $\mathrm{PB}$ and $\mathrm{VC}$ and 100\% PWR (Table 3). We also observed that by halving the amount of required water but application of both PB and VC, only about $21 \%$ of the root dry weight was reduced.

The results also showed that the tallest plants were observed in plots treated with a combination of $\mathrm{PB}$ and VC at $100 \%$ PWR, followed by those with the same amendments and $75 \%$ and 50\% PWR.

\section{Chlorophyll $\mathrm{a}$ and $\mathrm{b}$ and leaf ion leakage}

The highest amounts of chlorophyll $a$ and $b$ were observed in plots with 100\% PWR and a combination of $\mathrm{VC}$ and PB (Table 4). The interaction between VC and biochar also significantly influenced chlorophyll b concentration. At all deficit irrigation levels, chlorophyll b was higher in plots amended with $\mathrm{PB}$ or DPB alone or mixed with VC (Table 4). The amount of chlorophyll b decreased by only $32 \%$ at $50 \%$ PWR. In other words, by halving the amount of water consumed and the use of VC and $\mathrm{PB}$, the amount of chlorophyll b was less affected.

The highest ion leakage was obtained in the treatment with no amendments and 50\% PWR. The lowest ion leakage was observed in plots treated with both $\mathrm{VC}$ and $\mathrm{PB}$ at $75 \%$ and $100 \%$ PWR (Table 4 ).

\section{Leaf phenols and antioxidant capacity}

The total plant phenols were affected by deficit irrigation, vermicompost and biochar. The total phenols content of leaves was increased by $140 \%$ following application of $\mathrm{PB}$ alone at 50\% PWR. Similarly, the highest leaf antioxidant capacity was in plots amended with PB alone and at 50\% or $75 \%$ PWR. Application of vermicompost alone did not affect the antioxidant capacity of eggplant. Overall, the amount of antioxidant was higher in plants grown in plots with $50 \%$ and $75 \%$ deficit irrigation than plots with 100\% PWR.

\section{Leaf mineral nutrient concentrations}

The addition of a mixture of PB and VC at 100\% PWR resulted in the highest leaf nitrogen, while the lowest leaf nitrogen was observed in plants without amendments and at 50\% PWR (Table 4). The highest amounts of phosphorus, potassium and manganese were associated with plants treated with a combination of PB and VC at $100 \%$ PWR (Table 4). Overall, the amount of these elements in the leaf increased by the application of $\mathrm{PB}$ alone or in combination with VC. At all irrigation levels, the lowest leaf phosphorus, potassium and manganese concentration was found in plots with no amendments or only with VC (Table 4).

The highest leaf iron concentration was obtained from plants under combined application of $\mathrm{PB}$ and $\mathrm{VC}$ at 100\% PWR (Table 4). The lowest leaf iron was observed when no amendment was applied at 50\% PWR (Table 4). In general, amending soil with $\mathrm{PB}$ resulted in higher amounts of nitrogen, phosphorus, potassium, iron and manganese in the leaf compared to DPB. Moreover, plants grown in plots at $50 \%$ and $75 \%$ deficit irrigation showed lower concentrations of these mineral elements than those plants under $100 \%$ PWR.

\section{Leaf antioxidant enzymes}

Application of deficit irrigation, vermicompost, biochar and their interactions had significant effect on the concentrations of malondialdehyde, guaiacol peroxidase, superoxide dismutase and catalase enzymes of leaves $(P<0.05)$. The highest amount of these antioxidant enzymes as well as malondialdehyde were obtained from plants that received no amendments at 50\% PWR, followed by those treated with only VC at 50\% PWR (Table 4). Plants grown at $100 \%$ PWR, with or without amendments, showed low concentrations of these traits in the present study (Table 4).

\section{Plant water use efficiency}

Deficit irrigation, vermicompost, biochar and their interactions significantly $(P<0.05)$ affected the plant water use efficiency. The highest water use efficiency was in the plots treated with VC mixed with $\mathrm{DPB}$ or $\mathrm{PB}$ at $50 \%$ PWR, followed by the treatment with $\mathrm{PB}$ or DPB alone at 50\% PWR (Fig. 2).

\section{Plant yield}

The number of fruits per plant was affected by deficit irrigation, vermicompost, biochar and their interactions. Amending soil with a combination of $\mathrm{VC}$ and DPB, at $100 \%$ PWR resulted in the highest number of fruits per plant. Interestingly, combine application of DPB or PB with VC at $75 \%$ PWR also resulted in the highest number of fruits per plant (Fig. 3).

Application of a mixture of $\mathrm{VC}$ and $\mathrm{PB}$ or $\mathrm{DPB}$, at $100 \%$ PWR led to the highest average fruit weight. The lowest average fruit weight was obtained in the plots with no organic matter application and $50 \%$ or $75 \%$ PWR (Table 4).

The effect of deficit irrigation, biochar and the interaction of deficit irrigation and biochar on early yield 


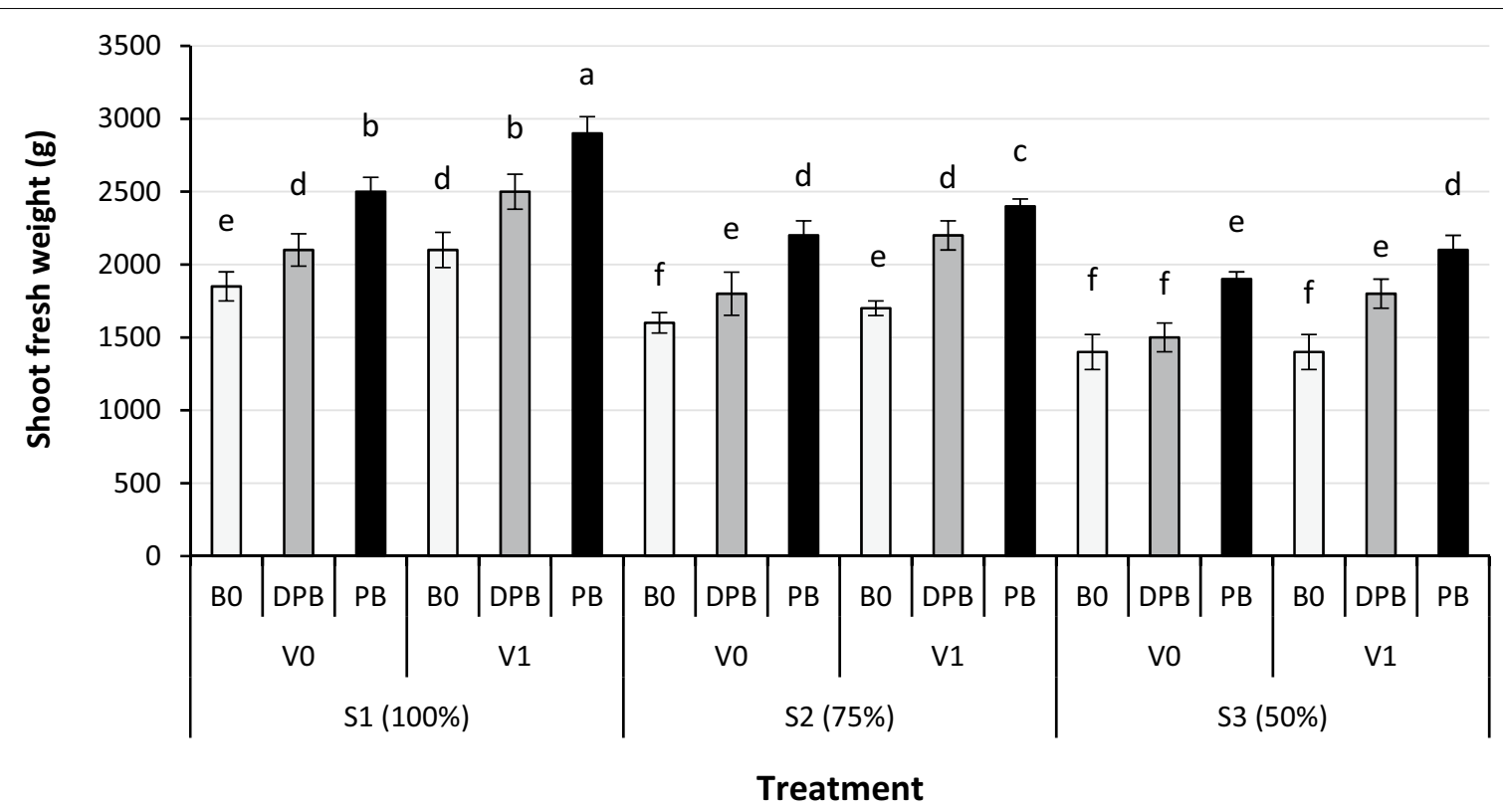

Fig. 1 The effect of biochar at three levels (B0: no biochar; DPB: $500 \mathrm{~g} \mathrm{~m}^{-2}$ date palm biochar and PB: $500 \mathrm{~g} \mathrm{~m}^{-2}$ pistachio biochar), vermicompost at two levels (V0: no vermicompost and V1: $1500 \mathrm{~g} \mathrm{~m}^{-2}$ vermicompost) and three levels of deficit irrigation (S1: 100\% water requirement; S2: 75\% water requirement and S3:50\% water requirement) on the shoot fresh weight of eggplant. The error bars followed by a different letter are significantly different at $P<0.05$ using the Duncan multiple range test

Table 3 The effect of vermicompost, biochar and deficit irrigation on growth of eggplant

\begin{tabular}{|c|c|c|c|c|c|}
\hline Treatment & Shoot DW (g) & Root FW (g) & Root DW (g) & Plant length (cm) & $\begin{array}{l}\text { Fruit } \\
\text { weight (g/ } \\
\text { plant) }\end{array}$ \\
\hline S1V0BO & $548.2 d$ & $155.1 \mathrm{f}$ & $62.3 \mathrm{e}$ & $93.5 \mathrm{C}$ & $499.1 \mathrm{ab}$ \\
\hline SIVODPB & $588.5 d$ & $207.5 \mathrm{e}$ & $86.3 c$ & $96.7 c$ & $511.3 a b$ \\
\hline S1VOPB & $700.4 b$ & $256.2 b$ & $102.7 b$ & $101.8 \mathrm{c}$ & $528.6 \mathrm{ab}$ \\
\hline S1V1B0 & $588.3 d$ & 186.3 e & $74.7 d$ & $101.7 c$ & $528.0 \mathrm{ab}$ \\
\hline S1V1DPB & $700.4 b$ & $246.4 b$ & $98.7 b$ & $112.7 b$ & $570.9 a$ \\
\hline S1V1PB & $812.2 \mathrm{a}$ & $282.4 \mathrm{a}$ & $114.7 \mathrm{a}$ & $125.0 \mathrm{a}$ & $584.0 \mathrm{a}$ \\
\hline S2VOBO & $448.2 \mathrm{e}$ & $126.2 f$ & $50.7 \mathrm{ef}$ & $81.5 d$ & $371.4 \mathrm{c}$ \\
\hline S2VODPB & $504.3 d$ & 176.8 e & $70.7 d$ & $87.0 \mathrm{~cd}$ & $451.8 \mathrm{~b}$ \\
\hline S2VOPB & $582.0 \mathrm{~d}$ & $226.9 c$ & $90.6 c$ & $91.6 \mathrm{~cd}$ & $464.6 \mathrm{~b}$ \\
\hline $\mathrm{S} 2 \mathrm{~V} 1 \mathrm{BO}$ & $476.1 \mathrm{e}$ & $156.6 f$ & $62.3 \mathrm{e}$ & $91.7 \mathrm{~cd}$ & $439.5 b$ \\
\hline S2V1DPB & $616.4 \mathrm{~cd}$ & $210.3 \mathrm{e}$ & $84.0 \mathrm{~cd}$ & $96.5 \mathrm{~cd}$ & $448.5 b$ \\
\hline S2V1PB & $672.3 c$ & $256.0 \mathrm{~b}$ & $102.6 b$ & $102.3 \mathrm{C}$ & $460.1 \mathrm{~b}$ \\
\hline S3VOBO & $392.2 \mathrm{e}$ & $94.0 \mathrm{~g}$ & $38.2 f$ & $79.5 d$ & $360.0 \mathrm{c}$ \\
\hline S3VODPB & $420.2 \mathrm{e}$ & $142.1 \mathrm{f}$ & $58.4 \mathrm{e}$ & $81.6 d$ & $432.0 \mathrm{~b}$ \\
\hline S3VOPB & $532.0 \mathrm{~d}$ & $191.3 \mathrm{e}$ & $78.5 \mathrm{~cd}$ & $86.8 \mathrm{~cd}$ & $445.6 b$ \\
\hline S3V1B0 & $392.1 \mathrm{e}$ & $126.2 \mathrm{f}$ & $50.8 \mathrm{ef}$ & $86.7 \mathrm{~cd}$ & $432.8 \mathrm{~b}$ \\
\hline S3V1DPB & $504.5 \mathrm{~d}$ & $176.8 \mathrm{f}$ & $70.3 d$ & $91.7 \mathrm{~cd}$ & $440.3 b$ \\
\hline S3V1PB & $588.6 \mathrm{~d}$ & $226.9 c$ & $90.8 c$ & $101.1 \mathrm{c}$ & $452.0 \mathrm{~b}$ \\
\hline
\end{tabular}

B0, no biochar; DPB, $500 \mathrm{~g} \mathrm{~m}^{-2}$ date palm biochar and PB, $500 \mathrm{~g} \mathrm{~m}^{-2}$ pistachio biochar; V0, no vermicompost and V1, 1500 $\mathrm{g} \mathrm{m}^{-2}$; $\mathrm{S} 1,100 \%$ water requirement; $\mathrm{S} 2$, $75 \%$ water requirement and $S 3,50 \%$ water requirement; FW, fresh weight; DW, dry weight

Different letters within each column are significantly different at $P<0.05$ using the Duncan multiple range test 


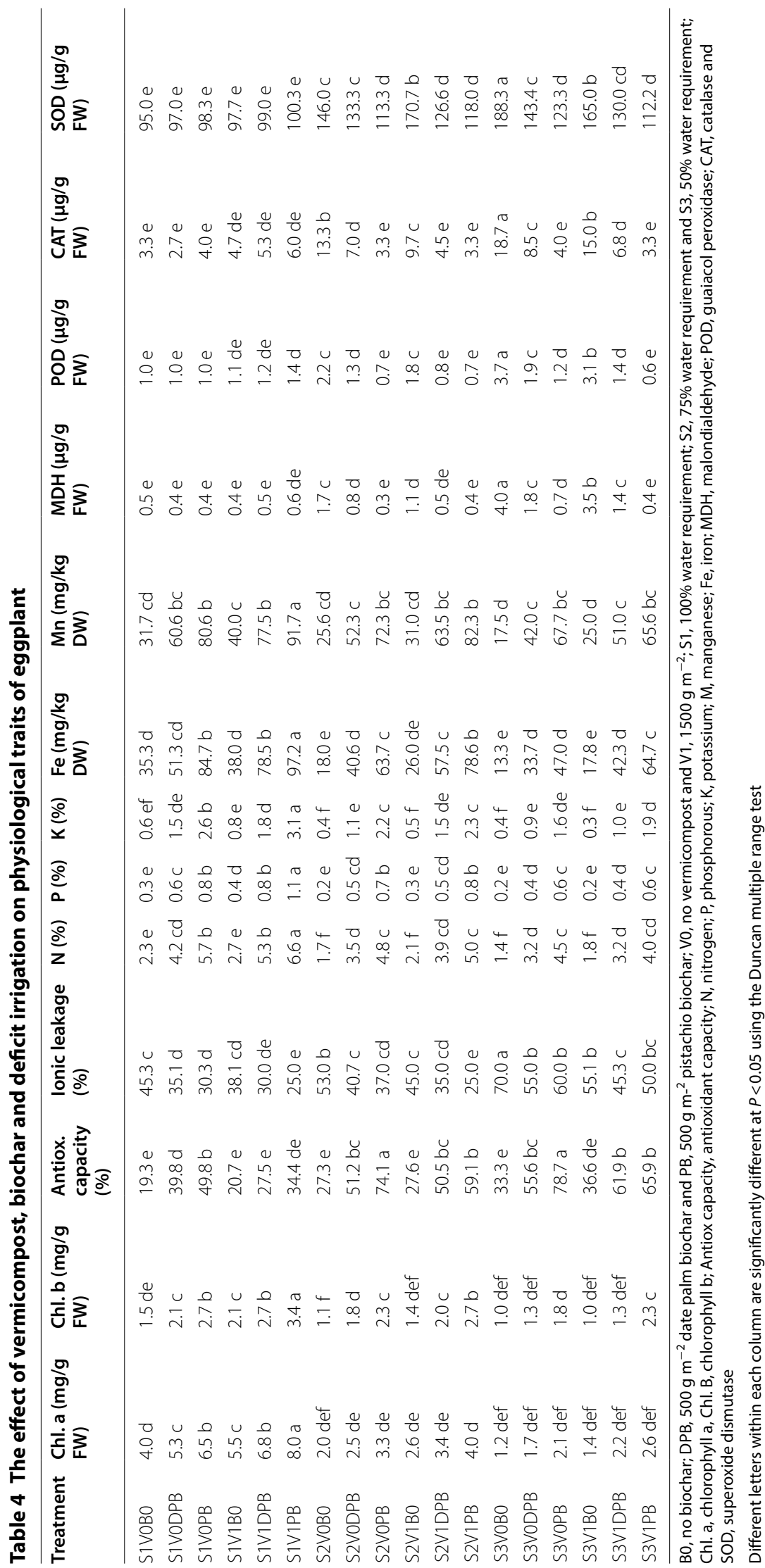


was also significant $(P<0.05)$. The highest early yield was obtained from plots treated with $\mathrm{PB}$ alone at $75 \%$ PWR, followed by those treated with PB or DPB mixed with VC at $50 \%$ and $75 \%$ PWR (Fig. 4). Total yield was affected by deficit irrigation, vermicompost, biochar and the interaction between deficit irrigation, vermicompost and biochar. The highest total yield was observed in plots amended with both $\mathrm{VC}$ and $\mathrm{PB}$ at $100 \%$ PWR, and this was 1.5 times higher than total yield obtained from plots without $\mathrm{VC}$ and biochar at 50\% PWR (Fig. 5). At all levels of the deficit irrigation, the total yield in plots treated with the combined application of DPB or PB with VC was higher than that in plots with no amendment.

\section{Discussion}

In this study, determination of leaf ion leakage, leaf antioxidant enzymes as well as reduction in most growth traits under deficit irrigation treatments show that plants were subjected to some degree of water stress particularly under 50 rather than $70 \%$ PWR. However, under mild deficit irrigation (70\% PWR) application of vermicompost and/or biochars were able to almost fully recover the hindered growth, but deficit irrigation at (50\% PWR) experienced significant reduction in plant growth and production despite it showed the highest water use efficiency when received organic amendments. Reduction in growth and productivity is common response of many crop to water deficit [27] and application of organic amendments have been shown to mitigate these negative effects [2]. The results showed that plant growth and yield were increased in the presence of both vermicompost and biochar, and combine application of $\mathrm{VC}$ with $\mathrm{PB}$ or DPB could compensate for up to $50 \%$ of water stress damage. This suggests that these amendments can, to a large extent, offset the stress caused by drought, mainly through increasing soil organic matter content, improving nutrient uptake and maintaining soil moisture that eventually increases the plant growth parameters $[21,29]$. In the present study, both biochar types and particularly applied vermicompost contained substantial amounts of N, P, Ca and Mg (Table 1), which eventually resulted in enhanced plant growth parameters and yield (Table 5). It has been shown that biochar amendment can increase the plant growth mainly due to increased nutrient availability and improved soil physical properties including reduced bulk density [8, 41]. Biochar with active functional groups improves soil chemical properties such as cation exchange capacity and enhances plant access to nutrients and consequently better plant growth [16]. Both pistachio and date palm biochars used in our experiment were $\mathrm{C}$-rich derived from branches of the trees with high cellulose,

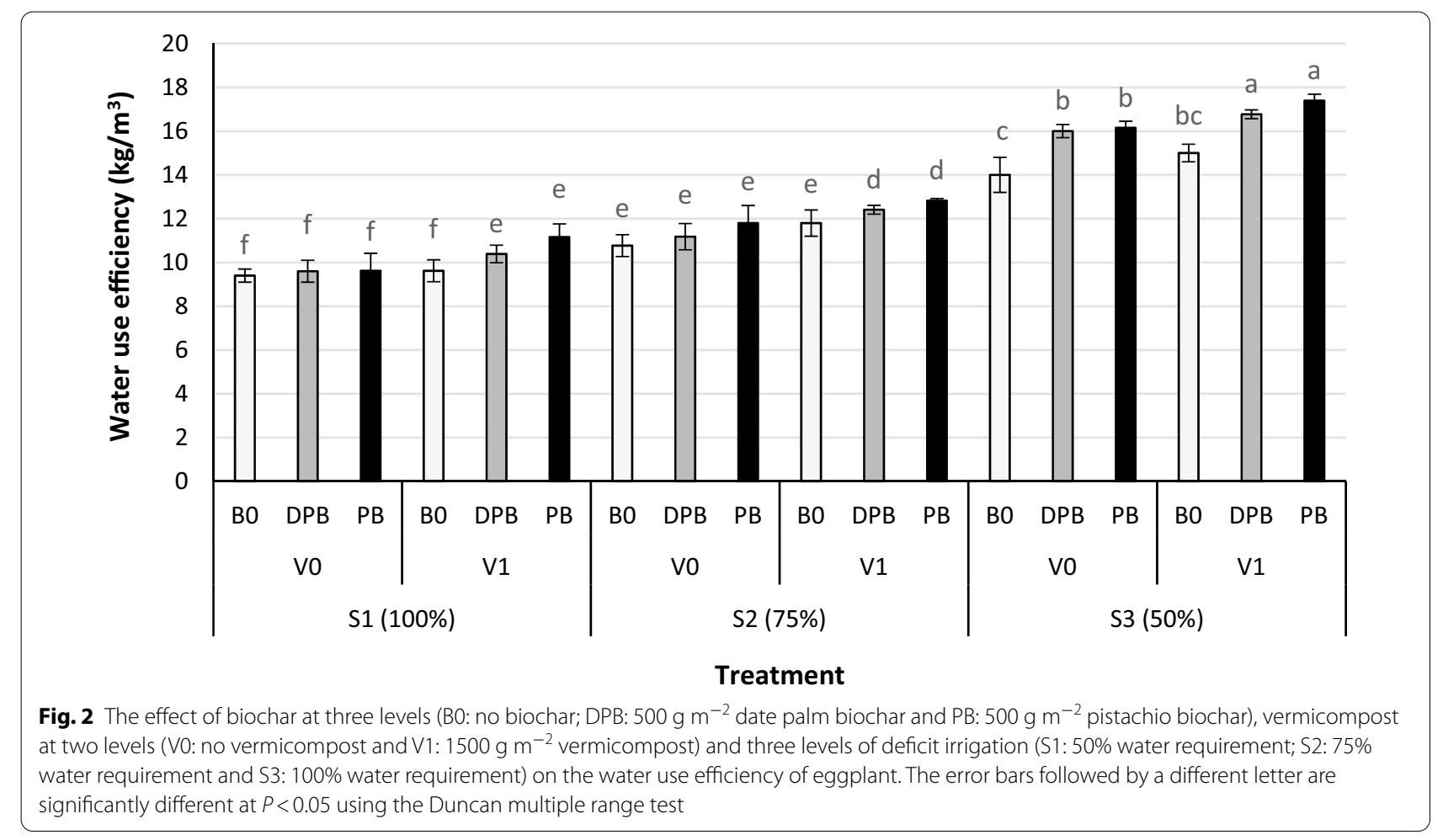


hemicellulose, and lignin content. Furthermore, these biochars were produced at high temperature of $560{ }^{\circ} \mathrm{C}$ for $4 \mathrm{~h}$. It has been shown that biochar production at such high temperatures leads to significant changes in the biochar's composition and increased surface area [20]. These biochars acted as a nutrient source as well as a suitable cation exchanger due to their large surface area resulting in the availability of nutrients and their higher uptake by plant roots. Moreover, an increase in the $\mathrm{pH}$ of biochar amended soil (Table 5 has implications on nutrient mineralization and availability mainly regarding base cations such as $\mathrm{Ca}, \mathrm{Mg}$ and $\mathrm{K}[4,29]$.

The plant height, which is an indicator of the plant growth and biomass production, was higher in the treatments with a mixture of $\mathrm{VC}$ and $\mathrm{PB}$ at all deficit irrigation levels. The shoot length was increased probably due to the role of biochar and $\mathrm{VC}$ in increasing minerals mainly the $\mathrm{P}$ availability that increases root growth and nutrient uptake as reported by Hussain et al. [15]. A combined effect of minerals bioavailability and plant hormones such as auxins and gibberellins are effective on plant height growth [34]. Similarly, application of biochar and vermicompost have increased the chlorophyll content, leaf photosynthesis and biomass production in other studies [31, 40]. In addition, increase in plant leaf area, leaf number, root length as well as root and shoot biomass have been frequently reported due to vermicompost and biochar application [5, 7, 27]. Plant roots grow well on substrates containing biochar; as the physicochemical conditions of the rhizosphere improve, a decrease in soil resistance to root growth is observed $[4,8]$. Biochar can also improve soil water permeability and facilitate root penetration and increase root colonization of bigger soil bulk [6].

Our results showed that leaf chlorophyll a and $b$ were increased by application of vermicompost and biochar. Similarly, application of biochar increased the amount of chlorophyll a and b mainly due to improving the uptake of $\mathrm{Mg}$ and $\mathrm{N}$ as essential macronutrients for chlorophyll biosynthesis $[8,42]$. The biochars and the vermicompost used in our trials contained a considerable amount of $\mathrm{Mg}$. On the other hand, the magnesium uptake by plant roots depends on the soil $\mathrm{pH}$, as it becomes more available at higher $\mathrm{pH}$ levels [21], therefore, biochar and vermicompost improved eggplant magnesium uptake by increasing the soil $\mathrm{pH}$.

The greatest amounts of N, P, K, Mn and Fe were observed in plants treated with $\mathrm{PB}$ and VC at $100 \%$ PWR. This could be mainly due to an increase in soil organic matter and enhanced water and nutrient storage capacity of soil by biochar and vermicompost. Vermicompost, while preserving water and nutrients, has a high amount of macro- and micro-elements that can be available to plants over the time $[30,40]$. Adequate soil organic

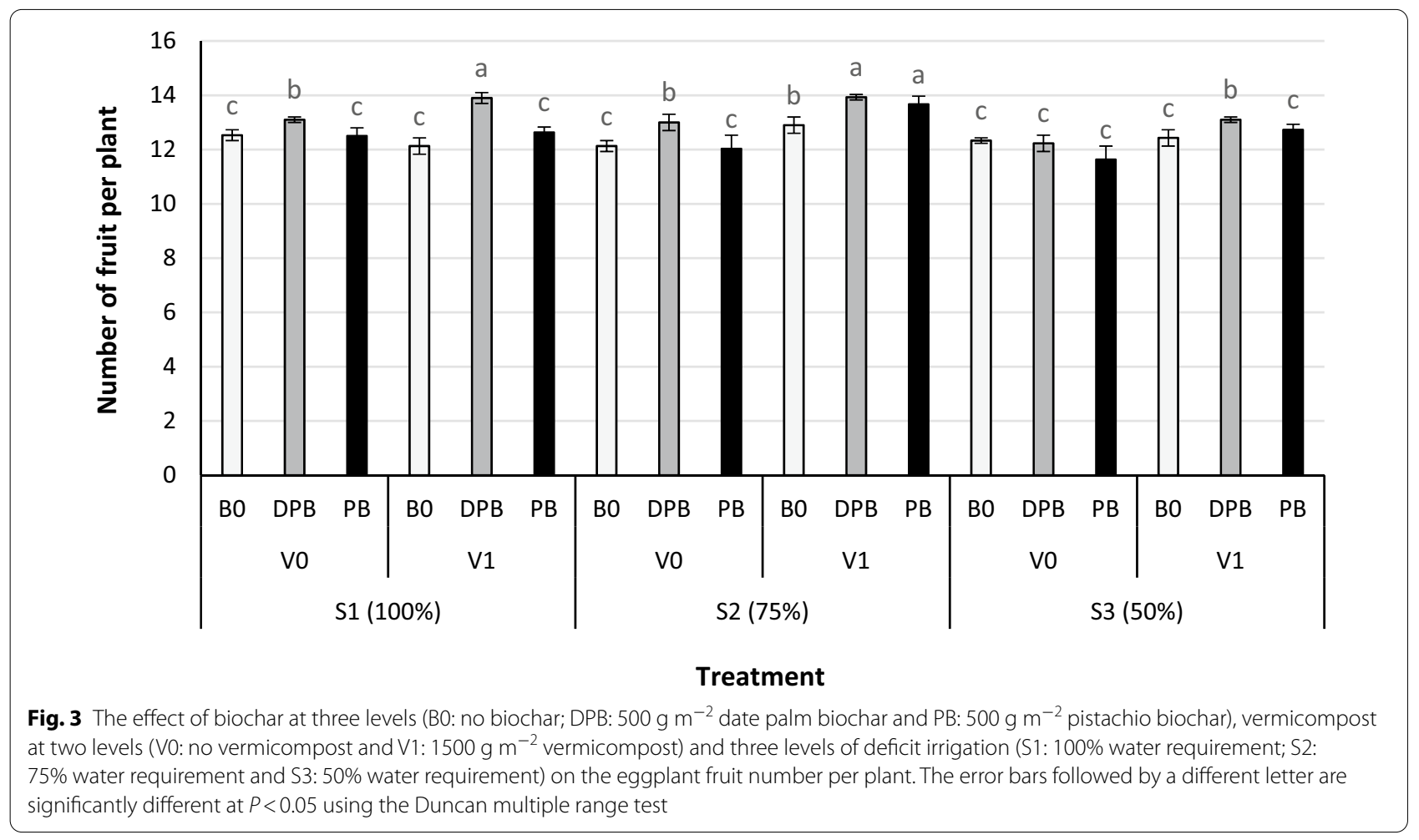




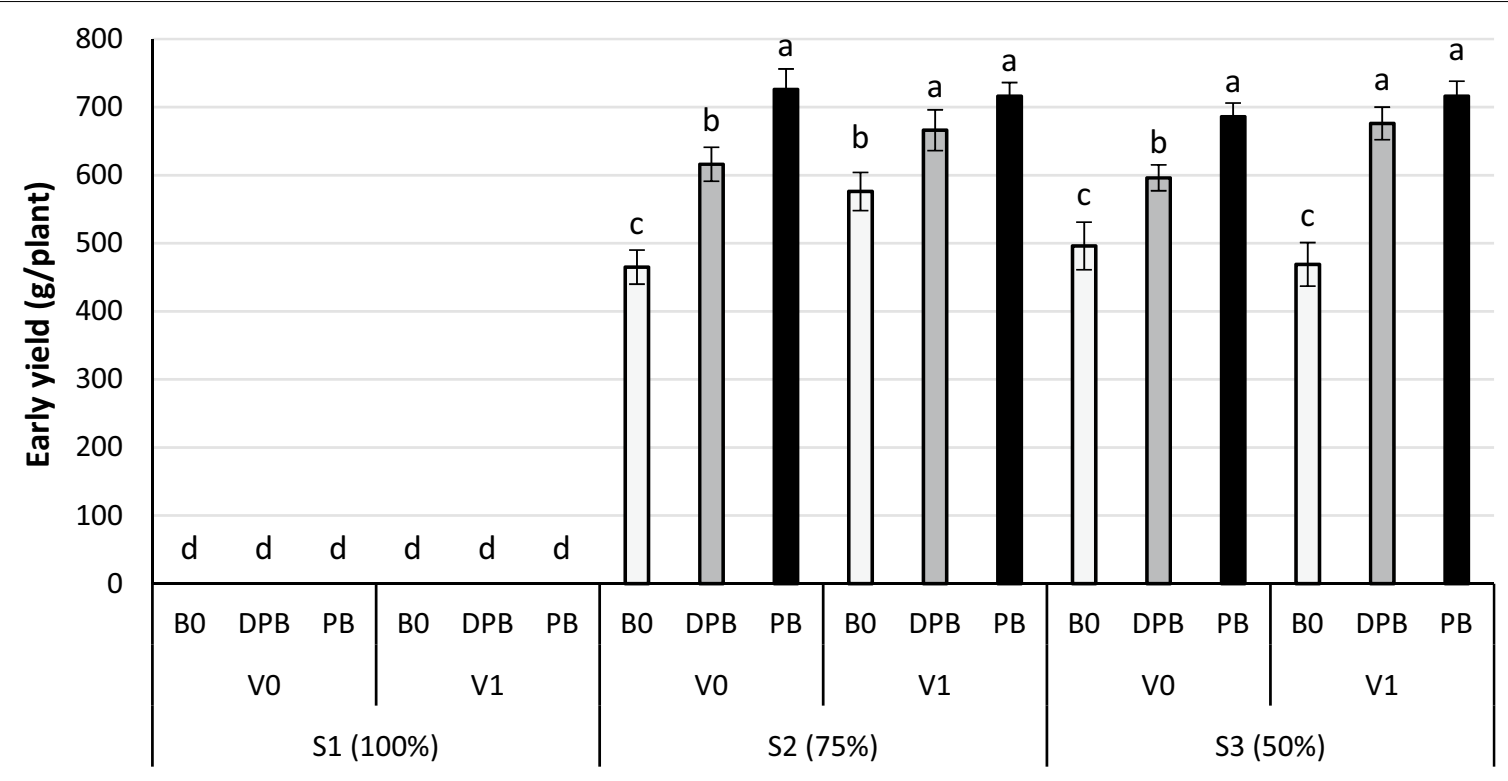

Treatment

Fig. 4 The effect of biochar at three levels (B0: no biochar; DPB: $500 \mathrm{~g} \mathrm{~m}^{-2}$ date palm biochar and PB: $500 \mathrm{~g} \mathrm{~m}^{-2}$ pistachio biochar), vermicompost at two levels (V0: no vermicompost and V1: $1500 \mathrm{~g} \mathrm{~m}^{-2}$ vermicompost) and three levels of deficit irrigation (S1: 100\% water requirement; S2: 75\% water requirement and S3: 50\% water requirement) on the early yield of eggplant. The error bars followed by a different letter are significantly different at $P<0.05$ using the Duncan multiple range test

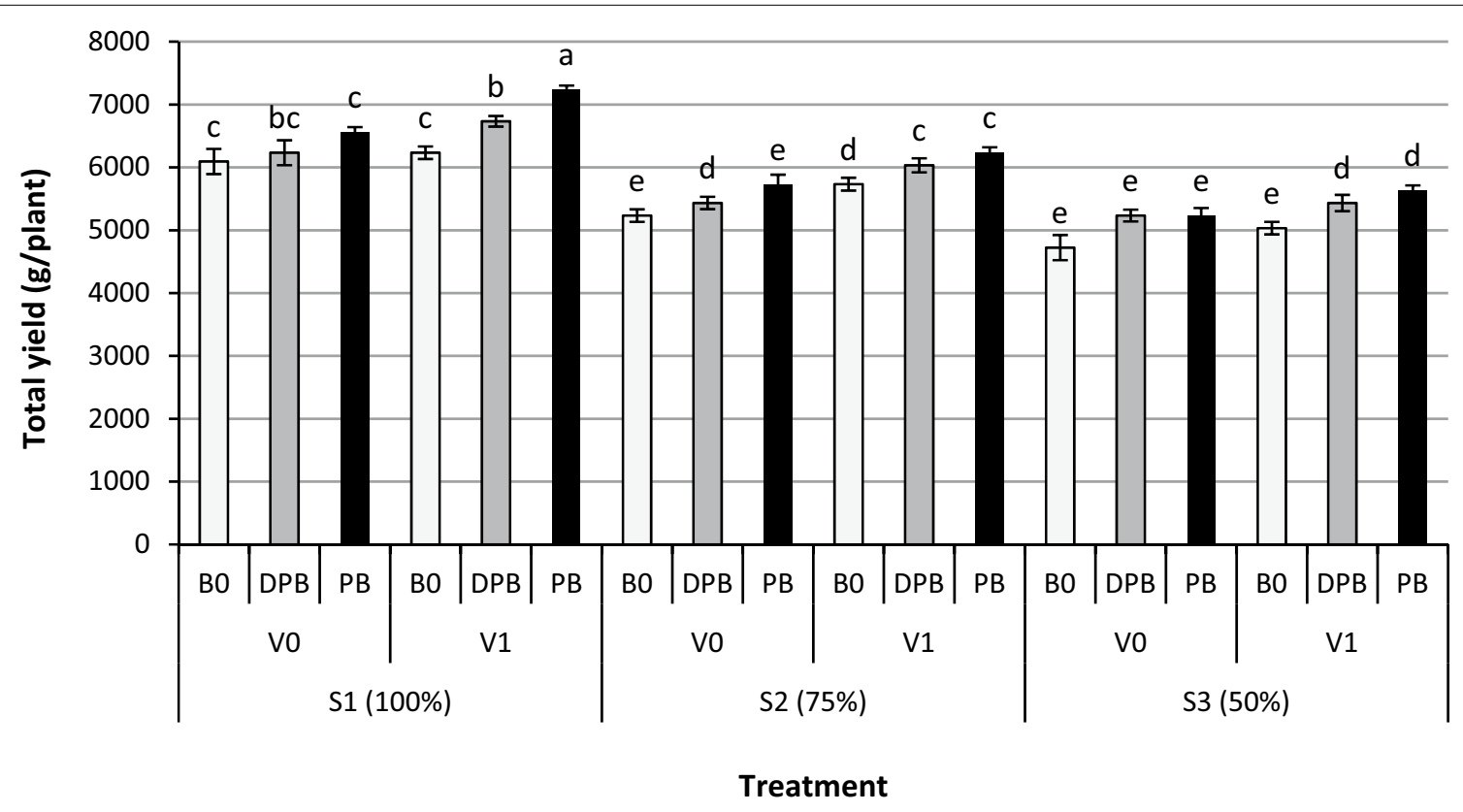

Fig. 5 The effect of biochar at three levels (B0: no biochar; DPB: $500 \mathrm{~g} \mathrm{~m}^{-2}$ date palm biochar and PB: $500 \mathrm{~g} \mathrm{~m}^{-2}$ pistachio biochar), vermicompost at two levels (V0: no vermicompost and V1: $1500 \mathrm{~g} \mathrm{~m}^{-2}$ vermicompost) and three levels of deficit irrigation (S1: 100\% water requirement; S2: 75\% water requirement and S3: 50\% water requirement) on the total yield of eggplant. The error bars followed by a different letter are significantly different at $P<0.05$ using the Duncan multiple range test 
matter can also prevent the loss of nutrients in the soil and reduce nitrate leaching [33]. In soil and plants, nitrogen is a mobile element and the availability and uptake and translocation of $\mathrm{N}$ is reduced under water shortage $[21,26]$. On the other hand, application of biochar can significantly improve soil water and $\mathrm{N}$ retention (in the root zone), but reduce minerals and nitrate leaching [18]. This can enhance $\mathrm{N}$ status of plant tissues as well. Biochar has high specific surface area mainly anionic adsorption capacity [23] and therefore, can absorb and store nitrate ions in the soil. Moreover, the microbial attractiveness of biochar and its high porosity can enhance soil biological processes such as mineralization, nitrification and other mineral-solubilization activities [23]. Biochar also prevents denitrification due to increased soil aeration and better uptake and retention of ammonium in the soil, leading to reduced nitrogen availability for denitrification bacteria [7].

The effect of organic matter on soil phosphorus uptake depends on their phosphorus content. Due to the low $\mathrm{P}$ content of the biochars used in our experiment, this increase could be attributed to acids released from organic matter [21]. The acids reduce the phosphorus fixation in the soil and make it accessible to the plant. Under soil dry conditions, P fixation is accelerated and root $\mathrm{P}$ uptake is reduced, however, various soils behave differently in their ability to stabilize phosphorus. It is well known that nutrients uptake and the water available to plant roots are closely related [32]. On the other hand, water relations affect all physiological processes associated with solubility and the availability of nutrients. Drought stress severely restricts the transfer of phosphorus to the shoots [21]. On the other hand, strategies that mitigate soil water shortage can increase minerals availability particularly P, Ca, K and N [32]. Similarly, biochar can retain soil $\mathrm{P}$ in an exchangeable form due to its high exchange capacity and water retention capacity resulting in enhanced plant $P$ uptake $[2,4]$.

The increase in soil soluble potassium associated with the application of biochar depends on the amount of potassium in the biochar, the rate of potassium release, and the effect of organic molecules on the release of potassium from soil minerals [25]. Application of different biochar types of wood and animal manure increased soil potassium [19]. It was observed that the K concentration was lower in plants under drought stress and by application of different biochars from plant residues in calcareous soil, an increase of more than $100 \mathrm{mg} \mathrm{kg} \mathrm{kg}^{-1}$ exchangeable potassium was achieved [25]. This might be due to the low availability of these elements under

Table 5 The effect of vermicompost, biochar and deficit irrigation on soil chemical properties

\begin{tabular}{|c|c|c|c|c|c|c|c|c|c|}
\hline Treatment & $\mathrm{pH}-\mathrm{KCl}$ & $\mathrm{EC}(\mu \mathrm{S} / \mathrm{cm})$ & SOC $\%$ & $\begin{array}{l}\text { Total N } \\
\%\end{array}$ & $\begin{array}{l}\text { Mineral N } \\
(\mathrm{mg} / \mathrm{kg})\end{array}$ & P-AL (mg/kg) & $\mathrm{Ca}-\mathrm{AL}(\mathrm{mg} / \mathrm{kg})$ & $\mathrm{K}-\mathrm{AL}(\mathrm{mg} / \mathrm{kg})$ & $\mathrm{Mg}-\mathrm{AL}(\mathrm{mg} / \mathrm{kg})$ \\
\hline S1VOBO & $7.2 \mathrm{c}$ & $5.2 \mathrm{c}$ & $0.7 c$ & $0.07 \mathrm{~b}$ & $8.3 b$ & $211.7 b$ & $713.5 c$ & $218.1 \mathrm{c}$ & $118.3 d$ \\
\hline S1VODPB & $8.9 \mathrm{a}$ & $7.2 \mathrm{a}$ & $1.5 \mathrm{a}$ & $0.08 b$ & $8.5 b$ & $219.3 b$ & $724.3 b$ & $231.5 b$ & $131.5 c$ \\
\hline S1VOPB & $7.9 b$ & $7.8 \mathrm{a}$ & $1.6 \mathrm{a}$ & $0.08 b$ & $8.6 \mathrm{~b}$ & $218.9 b$ & $730.8 \mathrm{~b}$ & $229.7 b$ & $127.3 c$ \\
\hline S1V1B0 & $7.9 b$ & $4.9 \mathrm{C}$ & $1.1 \mathrm{~b}$ & $0.10 \mathrm{a}$ & $12.0 \mathrm{a}$ & $222.0 \mathrm{a}$ & $772.1 \mathrm{a}$ & $284.2 \mathrm{a}$ & $195.2 \mathrm{a}$ \\
\hline S1V1DPB & $8.5 \mathrm{a}$ & $6.5 b$ & $1.5 \mathrm{a}$ & $0.10 \mathrm{a}$ & $12.3 \mathrm{a}$ & $224.1 \mathrm{a}$ & $798.7 a$ & $275.8 \mathrm{a}$ & 185.9 a \\
\hline S1V1PB & $8.0 \mathrm{~b}$ & $6.7 b$ & $1.5 \mathrm{a}$ & $0.10 a$ & $12.5 a$ & $229.2 \mathrm{a}$ & $782.5 \mathrm{a}$ & 269.9 a & $194.1 \mathrm{a}$ \\
\hline S2VOBO & $7.1 \mathrm{c}$ & $5.5 \mathrm{c}$ & $0.8 c$ & $0.07 b$ & $8.2 b$ & $210.1 b$ & $710.9 c$ & $215.2 \mathrm{c}$ & $110.6 d$ \\
\hline S2VODPB & $8.5 \mathrm{a}$ & $7.4 \mathrm{a}$ & $1.6 \mathrm{a}$ & $0.08 b$ & $8.5 b$ & $216.0 \mathrm{~b}$ & $721.6 b$ & $229.7 b$ & $129.9 c$ \\
\hline S2VOPB & $7.8 b$ & $7.7 \mathrm{a}$ & $1.5 \mathrm{a}$ & $0.07 b$ & $8.5 b$ & $215.8 b$ & $719.9 b$ & $228.1 \mathrm{~b}$ & $130.0 \mathrm{c}$ \\
\hline S2V1B0 & $7.8 \mathrm{~b}$ & $4.8 \mathrm{C}$ & $1.0 \mathrm{~b}$ & $0.10 \mathrm{a}$ & $11.8 \mathrm{a}$ & 229.9 a & $767.3 \mathrm{a}$ & $276.1 \mathrm{a}$ & $179.8 \mathrm{a}$ \\
\hline S2V1DPB & $8.4 \mathrm{a}$ & $6.7 b$ & $1.6 \mathrm{a}$ & $0.10 \mathrm{a}$ & $11.5 \mathrm{a}$ & $229.5 \mathrm{a}$ & $785.7 \mathrm{a}$ & $263.5 \mathrm{a}$ & 168.5 b \\
\hline S2V1PB & $8.0 \mathrm{~b}$ & $6.7 b$ & $1.5 \mathrm{a}$ & $0.10 \mathrm{a}$ & $11.9 \mathrm{a}$ & $231.4 \mathrm{a}$ & $790.2 \mathrm{a}$ & $265.0 \mathrm{a}$ & $175.5 \mathrm{ab}$ \\
\hline S3VOBO & $7.0 \mathrm{c}$ & $5.3 c$ & $0.7 c$ & $0.05 c$ & $8.7 \mathrm{~b}$ & $213.0 \mathrm{~b}$ & $709.5 \mathrm{c}$ & $214.3 c$ & $112.2 \mathrm{~d}$ \\
\hline S3VODPB & $8.8 \mathrm{a}$ & $7.1 \mathrm{a}$ & $1.4 \mathrm{a}$ & $0.08 b$ & $8.3 \mathrm{~b}$ & $219.6 \mathrm{~b}$ & $715.2 \mathrm{c}$ & $225.4 \mathrm{~b}$ & $121.5 \mathrm{c}$ \\
\hline S3VOPB & $7.8 \mathrm{~b}$ & $7.4 \mathrm{a}$ & $1.5 \mathrm{a}$ & $0.08 \mathrm{~b}$ & $8.1 \mathrm{~b}$ & $216.8 b$ & $715.0 \mathrm{c}$ & $226.0 \mathrm{~b}$ & $122.8 \mathrm{c}$ \\
\hline S3V1B0 & $7.7 b$ & $4.9 \mathrm{c}$ & $1.1 \mathrm{~b}$ & $0.10 \mathrm{a}$ & $11.4 \mathrm{a}$ & $227.1 \mathrm{a}$ & 758.7 a & $265.5 \mathrm{a}$ & $164.7 \mathrm{~b}$ \\
\hline S3V1DPB & $8.4 \mathrm{a}$ & $6.9 \mathrm{~b}$ & $1.5 \mathrm{a}$ & $0.10 \mathrm{a}$ & $11.0 \mathrm{a}$ & $228.4 \mathrm{a}$ & 769.8 a & $253.7 \mathrm{a}$ & $154.3 \mathrm{~b}$ \\
\hline S3V1PB & $7.9 \mathrm{~b}$ & $6.4 b$ & $1.5 \mathrm{a}$ & $0.10 \mathrm{a}$ & $11.0 \mathrm{a}$ & $227.6 \mathrm{a}$ & $770.5 \mathrm{a}$ & $258.5 \mathrm{a}$ & $149.1 \mathrm{~b}$ \\
\hline
\end{tabular}

$\mathrm{B} 0$, no biochar; $\mathrm{DPB}, 500 \mathrm{~g} \mathrm{~m}^{-2}$ date palm biochar and $\mathrm{PB}, 500 \mathrm{~g} \mathrm{~m}^{-2}$ pistachio biochar; $\mathrm{V} 0$, no vermicompost and V1, $1500 \mathrm{~g} \mathrm{~m}^{-2}$; $\mathrm{S} 1,100 \%$ water requirement; $\mathrm{S} 2$, $75 \%$ water requirement and S3,50\% water requirement; $\mathrm{EC}$, electrical conductivity; SOC, soil organic carbon; $\mathrm{P}-\mathrm{AL}$, ammonium lactate-extractable phosphorous; Ca$\mathrm{AL}$, ammonium lactate-extractable calcium; $\mathrm{K}-\mathrm{AL}$, ammonium lactate-extractable potassium; $\mathrm{Mg}-\mathrm{AL}$, ammonium lactate-extractable magnesium

Different letters within each column are significantly different at $P<0.05$ using the Duncan multiple range test 
low humidity. By increasing soil water content, monovalent ions including $\mathrm{K}$ increase more in the soil solution compared to divalent ions. On the other hand, over soil dryness, clay colloids adsorb more $\mathrm{K}$ to their surface and consequently $\mathrm{K}$ release and availability to plant roots is hindered [21]. Nevertheless, drought can significantly reduce plant potential and ability (restricted photosynthesis, leaf area, shoot and root growth) to absorb minerals.

The highest leaf $\mathrm{Fe}$ concentration was observed in the treatment amended with both $\mathrm{VC}$ and $\mathrm{PB}$ at $100 \%$ PWR. Amending soil with PB alone or mixed with VC increased the Fe content of the leaves at 50\% and $75 \%$ deficit irrigation. Water stress stops the activity of older roots, and only the tip of the roots absorbs nutrients. In this case, divalent cations such as iron are absorbed more than monovalent and the absorption of anions is limited [22]. Manganese and iron are inversely correlated in terms of plant uptake, therefore, increase in manganese uptake can reduce iron uptake [22]. Soil properties and its organic matter content in particular are important factors in micronutrient availability, and over organic matter decomposition their nutrients are released [33, 40]. Although several mechanisms are responsible for increasing or decreasing nutrient retention in soil, studies have shown that adding biochar to soil affects the ion exchange capacity and soil microbial activity [6].

The present study showed that the mixed application of VC with DPB or PB saves $50 \%$ of the water consumption, thus significantly increasing the water use efficiency. Vermicompost and biochar are well known to increase crops water use efficiency particularly under water stress conditions $[2,14,16,18,27]$. Their effective components such as plant growth hormones, minerals and organic compounds, as well as their physicochemical properties such as surface charges and colloidal behavior are also important in this regard [5, 24]. The highest water use efficiency in tomato was obtained with the wheat straw biochar and $70 \%$ of field capacity [16]. The experiments on Zinnia elegance (Dreamland Red) also showed that the highest water use efficiency was observed in treatments with vermicompost and $70 \%$ of field capacity [27].

By combined application of VC and DPB or PB, the highest number of fruits per plant was achieved. The fruit number per plant is one of the yield components, and the higher number of fruits per plant reduces fruits size and weight that are more marketable. Hence, incorporating vermicompost and pistachio or the date palm biochar in eggplant fields had a positive effect on the production of this vegetable crop and reduced water use by $25 \%$.

Application of PB alone or mixed with VC caused the highest early yield. Early crop yield is an important feature of production as some producers prefer to cultivate early varieties of vegetables. Early performance due to higher prices can offset the production costs. Therefore, by reducing water consumption by $25 \%$, we can achieve significant early yield while saving water consumption; this reduces the cost of production. The water saving practices are of great importance in arid cropping system, where water supply is an major limiting factor for plant growth [32]. According to our results, 25\% and 50\% decrease in irrigation and a combined application of $\mathrm{VC}$ and PB resulted in only $22 \%$ and $14 \%$ decrease in total yield, respectively. Therefore, these two organic materials can partially compensate for the effects of drought by maintaining water and nutrients without a significant reduction in yield. Our results are in line with the findings of Agbna et al. [2], who reported that the addition of $25 \mathrm{t} \mathrm{ha}^{-1}$ biochar reduced water use by $50 \%$ without affecting tomato yield.

Our results showed that both DPB and PB increased eggplant growth and yield. Previous studies have shown variable results for the impact of biochar on plant growth and yield $[6,15]$. This can be explained by the difference in compositions and structures of various types of biochar, which mainly depend on the pyrolysis conditions and original feedstock as mentioned above [10, 41]. Soil properties can also influence the performance of biochar $[7,11]$. Moreover, the combined application of biochar and vermicompost enhanced eggplant growth and yield compared with the application of biochar or vermicompost alone. Mixing compost with biochar can improve surface reactivity, increase the nutrient load, stimulate microbial colonization and degrade harmful substances of biochar and it may also affect compost quality as well [39]. Nevertheless, our results revealed that soil amendment with biochar and vermicompost could be a potential strategy for reducing the adverse effect of drought stress on eggplant growth and yield.

Our results also showed that antioxidant enzymes and ion leakage as well as malondialdehyde were higher under irrigation at 50\% PWR. Stress conditions particularly water stress is known to induce oxidative damage to plant tissues $[12,38]$. In protection response, plants enhance their defense mechanisms including several antioxidant compounds and enzymes [9, 24]. Therefore, an increase in plant cell antioxidants generally occurs under water stress conditions $[13,21]$. The amount of ion leakage and malondialdehyde indicate that some damage has been made on plant cells in treatments with $50 \%$ irrigation.

\section{Conclusions}

In this study, soil amendment with biochar and vermicompost showed positive effects on eggplant growth and yield, probably due to increasing soil organic matter 
content and associated positive effects on different soil characteristics, including better water and nutrient retention and availability. Application of vermicompost and particularly biochars increased N, P, K, Fe and Mn in plant leaves. Vermicompost amendment also enhanced the amounts of malondialdehyde, guaiacol peroxidase, superoxide dismutase and catalase enzymes. Application of vermicompost and the date palm or the pistachio biochar at 50\% PWR increased water use efficiency. Therefore, via application of vermicompost and biochar, it is possible to achieve an acceptable yield at 50\% PWR and save considerable amounts of water due to better water use efficiency (induced by these amendments) that is an essential feature, particularly in arid and semi-arid agriculture.

\section{Abbreviations}

PB: Pistachio biochar; DPB: Date palm biochar; VC:Vermicompost; FW: Fresh weight; DW: Dry weight; MDH: Malondialdehyde; SOD: Superoxide dismutase; CAT: Catalase; POD: Guaiacol peroxidase; PWR: Plant water requirement.

\section{Acknowledgements}

Not applicable.

\section{Authors' contributions}

ME designed and performed the experiments, analyzed the data and wrote the first draft of the manuscript; MKS, AM and NS supervised the research; all authors revised and edited the manuscript. All authors read and approved the final manuscript.

\section{Funding}

This research did not receive any specific grant from funding agencies in the public, commercial, or not-for-profit sectors.

\section{Availability of data and materials}

The datasets used and/or analyzed during the current study are available from the corresponding author on reasonable request.

\section{Ethics approval and consent to participate}

All authors listed have contributed significantly to the work and agree to be in the author list.

\section{Consent for publication}

All authors agree to publish the work.

\section{Competing interests}

The authors declare no competing interest.

\section{Author details}

${ }^{1}$ Department of Horticultural Science and Agronomy, Faculty of Agricultural and Food Sciences, Science and Research Branch, Islamic Azad University, Tehran, Iran. ${ }^{2}$ Department of Horticulture, Faculty of Agriculture, Tarbiat Modares University, Tehran, Iran. ${ }^{3}$ National Institute of Genetic Engineering and Biotechnology, Tehran, Iran. ${ }^{4}$ Department of Plant Protection, College of Aboureihan, University of Tehran, Tehran, Iran.

Received: 4 December 2020 Accepted: 13 February 2021 Published online: 06 April 2021

\section{References}

1. Aebi H. Catalases. In: Bergmeyer HV, editor. Methods of enzymatic analysis. New York: Academic Press; 1974. p. 673-84.
2. Agbna G, Dongli S, Zhipeng L, Elshaikh N, Guangcheng S, Timm L. Effects of deficit irrigation and biochar addition on the growth, yield, and quality of tomato. Sci Hortic. 2017:222:90-101.

3. Allen RG, Pereira LS, Raes D, Smith M. Crop evapotranspiration-guidelines for computing crop water requirements-FAO Irrigation and drainage paper 56. FAO; 1998.

4. Altland JE, Locke JC. Effect of biochar type on macronutrient retention and release from soilless substrate. HortScience. 2013;48:1397-402.

5. Alvarez JM, Pasian C, Lal R, Lopez R, Fernández M. Vermicompost and biochar as growing media replacement for ornamental plant production. J Appl Hortic. 2017;19:205-14.

6. Atkinson CJ, Fitzgerald JD, Hipps NA. Potential mechanisms for achieving agricultural benefits from biochar application to temperate soils: a review. Plant Soil. 2010:337:1-18.

7. Carter S, Shackley S, Sohi S, Boun-Suy T, Haefele S. The impact of biochar application on soil properties and plant growth of pot grown lettuce (Lactuca sativa L.) and cabbage (Brassica chinensis L.). Agronomy. 2013:3:404-18.

8. Chan KY, Zwieten LV, Meszaros I, Downie A, Joseph S. Using poultry litter biochars as soil amendments. Aust J Agric Res. 2008:46:437-44.

9. Chrysargyris A, Xylia P, Botsaris G, Tzortzakis N. Antioxidant and antibacterial activities, mineral and essential oil composition of spearmint (Mentha spicata L.) affected by the potassium levels. Ind Crop Prod. 2017;103:202-12.

10. Chatterjee S, Santos F, Abiven S, Itin B, Stark RE, Bird JA. Elucidating the chemical structure of pyrogenic organic matter by combining magnetic resonance, mid-infrared spectroscopy and mass spectrometry. Org Geochem. 2015;51:35-44.

11. D'Hose T, Debode J, De Tender C, Ruysschaert G, Vandecasteele B. Has compost with biochar applied during the process added value over biochar or compost for increasing soil quality in an arable cropping system? Appl Soil Ecol. 2020. https://doi.org/10.1016/j.apsoil.2020.103706.

12. Fu QS, Yang RC, Wang HS, Zhao B, Zhou CL, Ren SX, et al. Leaf morphological and ultrastructural performance of eggplant (Solanum melongena L.) in response to water stress. Photosynthetica. 2013;51:109.

13. Giannopolitis CN, Reis SK. Superoxide dismutase I. Occurrence in higher plants. Plant Physiol. 1977;59:309-14.

14. Haipeng WL, Cui Z, Guangming L, Jie C, Jin X, Jijun D, Juan L, Xiaodong L, Junfeng $C$, Ming L, Lunhui L, Liang H, Jia W. The interactions of composting and biochar and their implications for soil amendment and pollution remediation: a review. Cri Rev Biotechnol. 2017;37:754-64.

15. Hussain M, Farooq M, Nawaz A, Al-Sadi AM, Solaiman ZM, Alghamdi SS, Ammara U, OKY, Siddique KHM. Biochar for crop production: potential benefits and risks. J Soils Sediments. 2017;17:685-716.

16. Keabetswe L, Shao GC, Cui J, Lu J, Stimela TA. Combination of biochar and regulated deficit irrigation improves tomato fruit quality: A comprehensive quality analysis. Folia Hort. 2019;31:181-93.

17. Keiluweit M. Dynamic molecular structure of plant biomass-derived black carbon (biochar). Environ Sci Technol. 2010:44:1247-53.

18. Knowles OA, Robinson BH, Contangelo A, Clucas L. Biochar for the mitigation of nitrate leaching from soil amended with biosolids. Sci Total Environ. 2011;409:3206-10.

19. Laird DA, Fleming P, Davis DD, Horton R, Wang B, Karlen DL. Impact of biochar amendments on the quality of a typical Midwestern agricultural soil. Geoderma. 2010;158:443-9.

20. Marra R, Vinale F, Cesarano G, Lombardi N, d'Errico G, Crasto A, Mazzei P, Piccolo A, Incerti G, Woo SL, Scala F, Bonanomi G. Biochars from olive mill waste have contrasting effects on plants, fungi and phytoparasitic nematodes. PLoS ONE. 2018. https://doi.org/10.1371/journal.pone.01987 28.

21. Marschner P. Marschner's mineral nutrition of higher plants. 3rd ed. London: Elsevier; 2011.

22. Martins ALC, Batagha OC, Camargo OA, Contarella H. Corn yield and uptake of $\mathrm{Cu}, \mathrm{Fe}, \mathrm{Mn}$ and $\mathrm{Zn}$ from sewage sludge-amend soil with and without liming. Revista de Ciencias Sociales. 2003;27:563-74.

23. Mukherjee A, Hamdan R, Cooper WT, Zimmerman ARA. Chemical comparison of freshly-produced and field-aged biochars and biocharamended soils. Chemosphere Solid Earth Discussions. 2013;6:731-60.

24. Naiji M, Souri MK. Nutritional value and mineral concentrations of sweet basil under organic compared to chemical fertilization. Acta Sci Pol Hortorum Cultus. 2018;17(2):167-75. 
25. Najafi-Ghiri M. Effect of different biochars application on some soil properties and potassium pools distribution in a calcareous soil. Iran J Soil Sci. 2015;29:351-8.

26. Najarian A, Souri MK. Influence of sugar cane compost as potting media on vegetative growth, and some biochemical parameters of Pelargonium $\times$ hortorum. J Plant Nutr. 2020;43(17):2680-4.

27. Nazarideljou MJ, Heidari Z. Effects of vermicompost on growth parameters, water use efficiency and quality of Zinnia Bedding plants (Zinnia elegance 'Dreamland Red') under different irrigation regimes. Int J Hortic Sci Technol. 2014;1:141-50.

28. Polle A, Otter T, Seifert F. Apoplastic peroxidases and lignification in needles of Norway Spruce Picea abies L. Plant Physiol. 1994;106:53-60.

29. Prasad M, Tzortzakis N, McDaniel N. Chemical characterization of biochar and assessment of the nutrient dynamics by means of preliminary plant growth tests. J Environ Manag. 2018;216:89-95.

30. Pathma J, Sakthivel N. Molecular and functional characterization of bacteria isolated from straw and goat manure based vermicompost. Appl Soil Ecol. 2013;70:33-47.

31. Song W, Guo M. Quality variations of poultry litter biochar generated at different pyrolysis temperatures. J Anal Appl Pyrol. 2012;94:138-45.

32. Souri MK, Hatamian M. Aminochelates in plant nutrition: a review. J Plant Nutr. 2019:42(1):67-78.

33. Souri MK, Naiji M, Kianmehr MH. Nitrogen release dynamics of a slow release urea pellet and its effect on growth, yield, and nutrient uptake of sweet basil (Ocimum basilicum L.). J Plant Nutr. 2019;42(6):604-14.

34. Souri MK, Yaghoubi SF. Benefits of organic fertilizers spray on growth quality of chili pepper seedlings under cool temperature. J of Plant Nutr. 2019;42(6):650-6.

35. Taromi Aliabadi B, Hassandokht MR, Etesami H, Alikhani HA Dehghanisanij $\mathrm{H}$. Effect of mulching on some characteristics of tomato (Lycopersicon esculentum Mill.) under deficit irrigation. J Agric Sci Technol. 2019;21(4):927-41.
36. Taher D, Solberg S, Prohens J, Chou Y, Rakha M, Wu T. World vegetable center eggplant collection: origin, composition, seed dissemination and utilization in breeding. Front Plant Sci. 2017:8:1484.

37. Tzortzakis NG, Tzanakaki K, Economakis CDCD. Effect of origanum oil and vinegar on the maintenance of postharvest quality of tomato. Food Nutr Sci. 2011;2:974-82.

38. Valentovic P, Luxova M, Kolarovic L, Gasparikova O. Effect of osmotic stress on compatible solutes content, membrane stability and water relations in two maize cultivars. Plant Soil Environ. 2006;52:186-91.

39. Vandecasteele B, Sinicco T, D'Hose T, Vanden Nest T, Mondini C. Biochar amendment during composting or compost storage affects compost quality and $\mathrm{N}$ losses but not $\mathrm{P}$ plant uptake. J Environ Manage. 2016:168:200-9.

40. Wang X-X, Zhao F, Zhang G, Zhang Y, Yang L. Vermicompost improves tomato yield and quality and the biochemical properties of soils with different tomato planting history in a greenhouse study. Front Plant Sci. 2017:8:1978.

41. Windeatt JH, Ross AB, Williams PT, Forster PM, Nahil MA, Singh S. Charac teristics of biochars from crop residues: potential for carbon sequestration and soil amendment. J Environ Manage. 2014;146:189-97. https:// doi.org/10.3389/fpls.2017.01978.

42. Zargar Shooshtari F, Souri MK, Hasandokht MR, Kalate JS. Glycine mitigates fertilizer requirements of agricultural crops: case study with cucumber as a high fertilizer demanding crop. Chem Biol Technol Agri. 2020;7(1):1-10.

\section{Publisher's Note}

Springer Nature remains neutral with regard to jurisdictional claims in published maps and institutional affiliations.

\section{Submit your manuscript to a SpringerOpen ${ }^{\circ}$ journal and benefit from:}

- Convenient online submission

- Rigorous peer review

- Open access: articles freely available online

- High visibility within the field

- Retaining the copyright to your article

Submit your next manuscript at $\boldsymbol{\nabla}$ springeropen.com 